\title{
تكنولوجيا المعلومات وأثرها على الميزة التنافسية \\ دراسة ميدانية في شركات السياحة والسفر الميزف الأردنية
}

د.شحاده مفلح الغرايبه

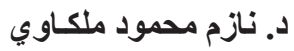

\section{The Impact of Information Technology on Competitive Advantage: An Emperical study at Jordanian Tourist Companies}

Abstract: The study aimed at recognizing information technology level and its impact on the competitive advantage in Jordanian travel and tourism companies. The population of the study included all employees in Jordanian travel and tourism category (A) companies (total number of 77), out of which a random sample of (34) companies were selected. Data were collected from three administrative levels of employees in departments utilizing computers and information technology in these tourism companies. Out of (210) questionnaires distributed, (186) valid for analysis were retrieved.

Results proved that information technology used in the travel and tourism companies assigned to the study is highly efficient. Results also verified that the information technology used has a significant effect on the competitive advantage and its different dimensions (cost, quality, creativity, delivery and flexibility).

The study recommends the need for more attention, development and role enhancement of information technology on the competitive advantage in the tourism sector in general and the transport and tourism companies in particular.

Keywords: information technology, competitive advantage, Jordanian travel and tourism companies, Jordan

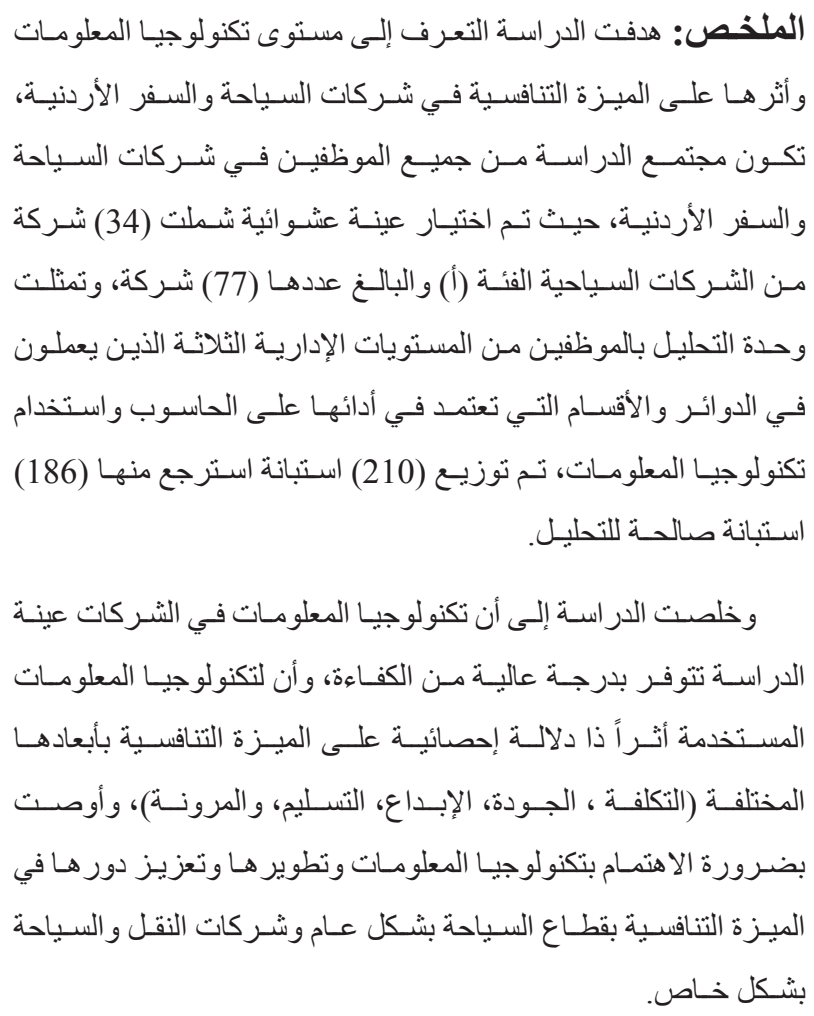


الأردن، فهـو القطــاع الأكتثر مو اكبـة مـع التطــور ات التكنولوجيـة التـي تحـدث في العالـم، لذلكلك يمكن القـول انـه كلمـا كانـت شـركات السـياحة و السـفر متقدمـة فـي مجـال التكنولوجيـا، كلمـاز ادت تتافسـية الثــركات

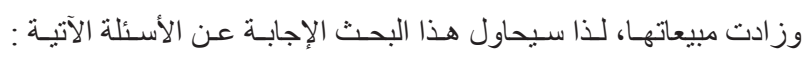

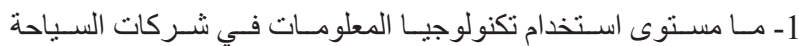

$$
\text { و السـفر الأردنيـة؟؟ }
$$

2- هـل يوجد علاقـة بيـن مسـتوى تكنولوجيـا المعلومـات ومسنتوى الميزةة

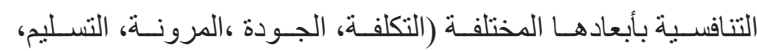
الإبـداع) فـي شـركات السـياحة و السـفر الأردنيـة مـن وجهـة نظـر

العامليـن فيهـا؟

3- هـل يؤثخر اسـتخدام تكنولوجيـا المعلومــات على الميـزة التنافسية في

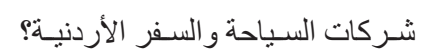

\section{أهداف الاراسة}

تهـدف الدراســة التعـرف إلـى العلاقـة بيـن مسـتوى اسـتخدام

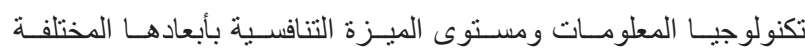
(التكلفـة، الجـودة، المرونـة، التسـليم ،الإبـداع ) مـن وجهـة نظـر الموظفيـن في شـركات السياحة والسـفر الأردنيـة، والكثـف عن تأثيـر تكنولوجيـا

$$
\text { المعلومـات على الميـزة التنافسـية فيهـا. }
$$

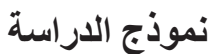

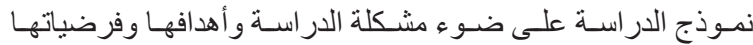
واسـتناداً إلى عـدة مر اجـع منهـا ( Laodon,2014, Kronkie, 2011,

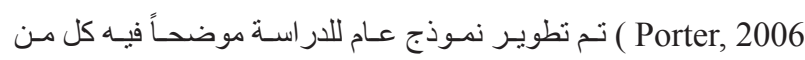

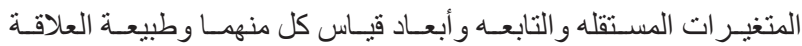

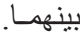
الشكل (1) يمثل نموذج الدر اسة المعتمد.

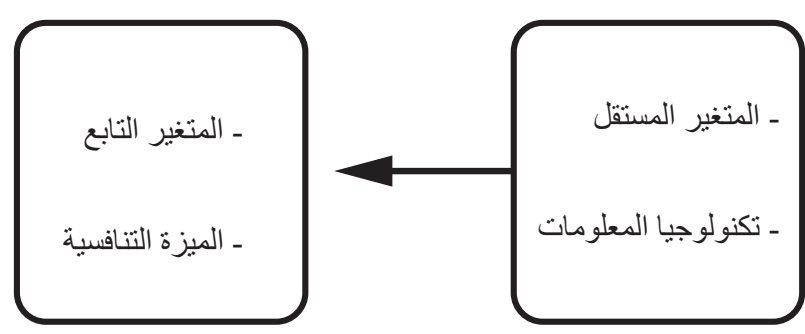

الثكل (1) نموذج الدراسة

\section{فرضيات الاراسة

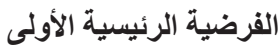

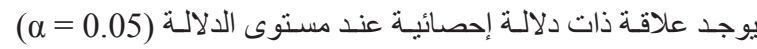
بين تكنولوجيـا المعلومـات و الميزة التنافسية ـ ويتفرع منهـا مـا يلي:

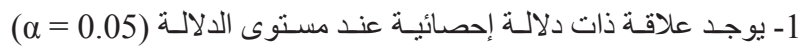
بيـن تكنولوجيـا المعلومـات و التكلفـة.

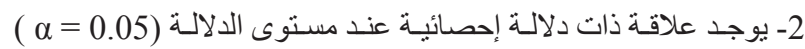

\section{أولاً : الإطار العام للاراسة}

المقدمة أمة

شـهد قطــاع تكنولوجيـا المعلومــات تطــور اً سـريعا وملحوظـاً فـي

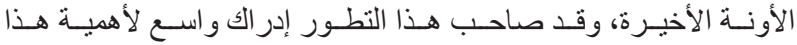

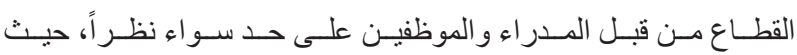
انعكس اثـر هــا التطـور علـى مختلـــ مجـالات الحيـاة وقطاعـات

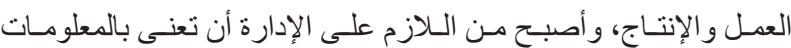

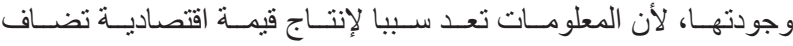

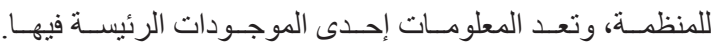
إن اسـتخدام منظمـات الأعمــال لتكنولوجيـا المعلومــات يمكنهــــــن إحــاث تغيـر يـؤدي إلـى رفـع كفــاءة الوظائـف التشــيلية و الإداريـة

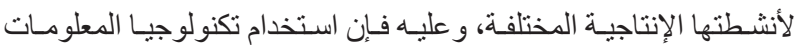

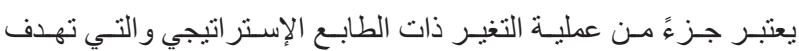

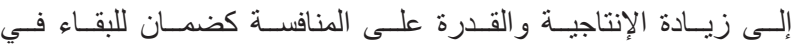
السـوق، كمـاو تلعـب تكنولوجيـا المعلومـات دور اً في تحسين و تطويـر

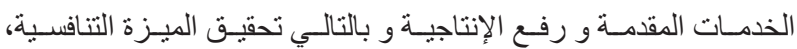

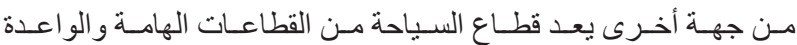

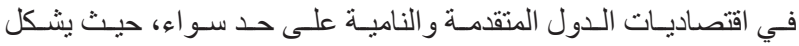

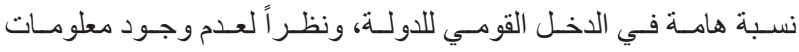
موتقــة عـن طبيعـة هــا الأثـر فـي شـركات السـياحة و السـفر الأردنيـة، تحساول هذه الدر اسـة معرفـة أثر تكنولوجيـا المعلومـات في تعزيـز الميزة التنافسية في هـذه الثـركات.

\section{أهمية الار اسة - ماسة}

تكــن أهميـة الدر اســة فـي التعـرف إلـى و اقـع اسـتخدام تكنولوجيـا المعلومـات فـي شـركات السـياحة و الســفر الأردنيـة، و علاقتهــا بجـودة الخدمـات و كفـاءة العمليـات. و جـاءت هـذه الدر اسـة بمثابـة دعـوة إلىى

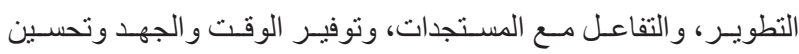

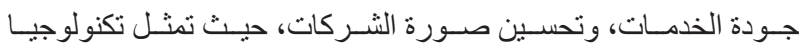
المعلومـات مصــدر ا رئيسـيا لتغذيـة مختلـف عمليـات و أنثـطة شـركات السياحة و السـفر الأردنيـة بالمعلومـات التـي تمكنهـا مـن جمع و تخزيـن و تبويـبـ وتحليـل المعلومــات و الاسـتفادة منهــا بسـر عة و دقــة عاليــة.

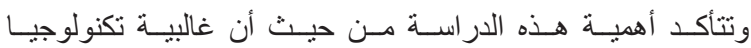
المعلومـات لا زالـت تعـد بعيدةً عـن تحقيـق الميـزة التنافسـية للمنظمـات

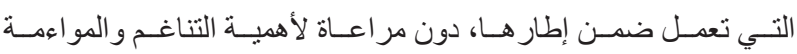
التي يجب أن تكون بينهــا، ومنهـا شـركات السـياحة و السـفر الأردنيـة، الأمـر الذي أدى إلى أن يكـون أثنر تقنيـة المعلومـات محدوداً في معظم الحالات، و هو ما تسعى هذه الدر اسة إلى در استه وتعزيزه.

مشكلة الاراسة يعـد قطــاع السـياحة و السـفر مـن القطاعـات الحيويـة المهمـة فـي 
الإداريـهـ و الميـزة التنافسية وهـي الأكثر اسـتخداماً و إدر اكاً لهـذه التقنيـة

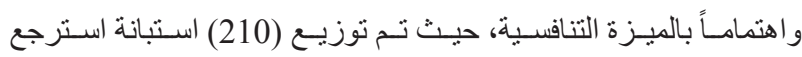
منهـا (186) اسـتبانة صالحـة للتحليـل. أساليب جمع البيانات

اعتمدت الدر اسة على نوعين من المصادر لجمع البيانات 1- المصــادر الثانويـة: تــم التركيـز على المو اقـع المتوفـرة على شـبكة

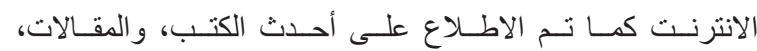

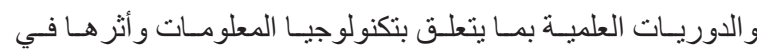
تحقيـق الميـزة التنافسـية للمنظمـات. 2- المصــادر الأوليـةة: تتمثـل فـي جمـع البيانـات بو اسـطـة اسـتبانة تـم

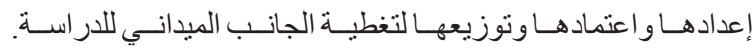

ثانياً: الإطار النظري

\section{مفهوم تكنولوجيا المطلومات وأهميتها}

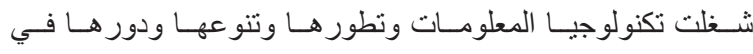
التأثيـر على نجـاح المنظمـات مســاحةً كبيـرةً مـن اهتمامــات الباحثبـن و التقنييـن و الإدارييـن ومنظمـات الأعمـال خـلال الحقبـة الماضيـة، حيـث دخلت هـذه التكنولوجيـا جميـع وظائف المنظمـات كالتخطيط و التنظيـم

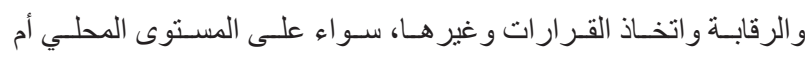
المستوى الدولي، و أصبحت المعلومـات قوة مؤثرة تتحكم في مختلف نو احي الحيـاة، و باتـت مختلف عمليـات و نشـاطات الثـركات تركز إلى ونى حـد كبيـر على حجـم و نوعيـة المعلومــات المتو افـرة لديهـا ( العامـري،

و تعتبـر تكنولوجيـا المعلومـات القاعـدة الأساسـية التـي تبنـي على

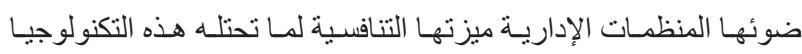

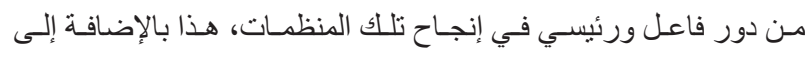

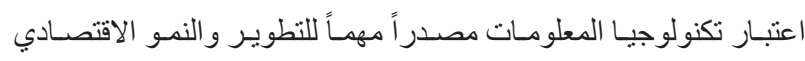
لتلـك المنظمـات، و لا تسـتطيع أيـة منظمـة جمـع و تخزيـن المعلومـات و

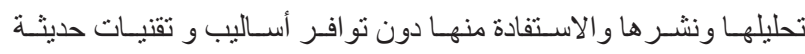
ومتطورة، كمـاو أصبح الحاسـوب، و البرمجيـات، و شبكات الحاسـوب، و نظم المعلومـات، و نظم الذكاء الصناعي، و الانترنتـ و غير هـا جز عاً

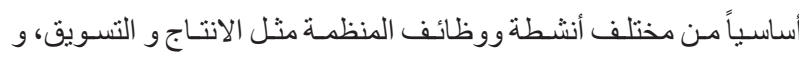
الماليـة وغير هـا ( العامـري، 2008).

وتعرف تكنولوجيـا المعلومـات Information Technology بأنها المكونـات الماديـة و البرمجيـات ووسـائل الاتصـال عن بعد، و إدارة قو اعد

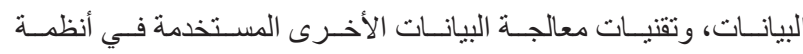
المعلومـات المعتمـدة على الحاسـب، أي أن أنظمـة المعلومـات مـن وجهـة نظـر الباحث تمثل الحاجـات المعينـة للمنظمـة لتحقيق التعامـل المتكامـل

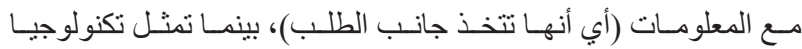
المعلومـات جانب العـرض لأنها تلبـي الحاجـات وتقدم الوسـائل المختلفـة
بين تكنولوجيـا المعلومـات و الجودة.

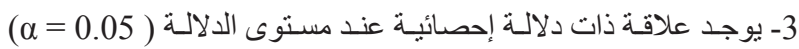

بيـن تكنولوجيـا المعلومـات و المرونــة.

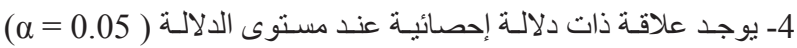

بين تكنولوجيـا المعلومـات و التسـليح.

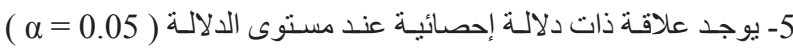
بين تكنولوجيـا المعلومـات و الإبـداع.

\section{الفرضية الرئيسية الثاتية}

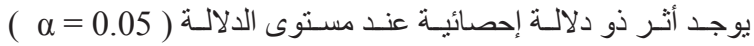

لتكنولوجيـا المعلومـات على الميـزة التنافسية ويتفرع عنهـا مـا يلي:

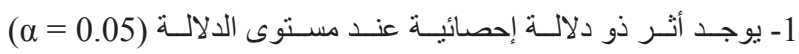
لتكنولوجيـا المعلومــات علـى التكلفــة.

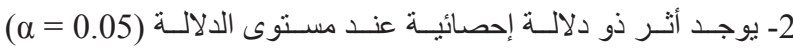

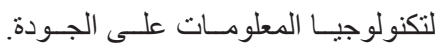

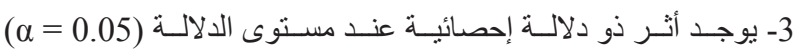
لتكنولوجيـا المعلومــات علـى المرونـــة.

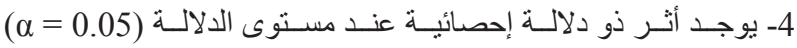
لتكنولوجيـا المعلومـات علـى التسـليه.

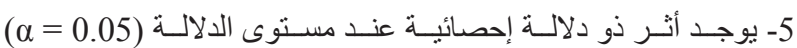
لتكنولوجيـا المعلومــات علـى الإبـداع. الفرضية الرئيسية الثالثة

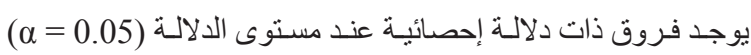
بيـن إجابـات أفـر اد عينــة الدر اسـة لتطبيـق مجـال تكنولوجيـا المعلومـات تعـزى للمتغيـرات ( الجنس، العهـر، المؤهـل العلمي، مـدة الخدمـة).

\section{منهجية الارراسة}

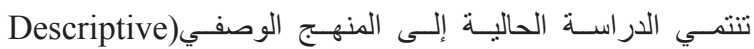
(Methodology

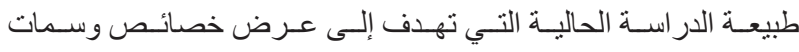
هيكليهـ وتنظيميـه محدده ، وبالاضـافه إلى ذلك فـان هذا المنهج يتجـاوز جــع البيانـات ووصـف الظو اهـر إلى تحليـل و اشـتقاق الاستتنتاجات ذات الالالـة بالنســبة للمشـكلة التـي يعالجهـا البحــث.

\section{مجتمع وعينة الاراسة}

تكون مجتمـع الدر اسـة مـن جميع شـركات السـياحة و السـفر الأردنيـة

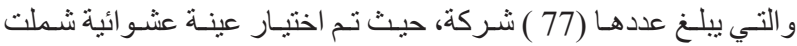

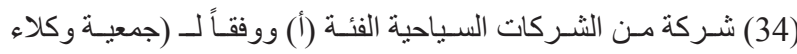
السياحة و السـفر الأردنيـة www.jsta.org.jo. ( w ).

كمـا تـم إختيـار وحـدات معينـة ضمـن كل شـركه لتوزيـع الاسـتبانة عليهـا بحيث تعبـأ مـن قبـل العاملين فيها وشـلت (وحدة نظم المعلومات ووحدة التسـويق)، كون الدر اسـه تتتـاول موضـوع تكنولوجيـا المعلومـات 
وخزنها ونقلها وتداو لها و استرجاعها واستقبالها وبثهـا للمستخدمين

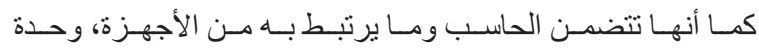

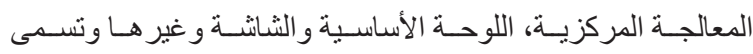
بالمكونـات الماديـة .

2- البرمجيـات : وتعنـي برامــج الحاسـوب التـي تعمـل علـى إدارة

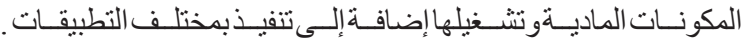
3- قو اعد البيانـات : و هـي مجمو عـة بيانـات مرتبطـة مـع بعضهـا أو هي المعلومـات المخزونـة في أجهزة ووسـائل خزن البيانـات . 4- الاتصـالات بعيدة المدى: وهي المكون الأخير لتكنولوجيـا المعلومات ويعتقد البعض أنها الأكثر أهميـة فهي أدوات أو وسـائل الاتصـالات عن بعد مثنل الهو اتف، الفاكس، و الألياف الضوئيـة ومكوناتها.

\section{خصائص تكنولوجيا المعلومات والاتصالات}

بمكن تحديـد أهم خصـائص تكنولوجيـا المعلومـات و الاتصـالات بمـا

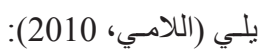

1- تقليص المسافات: فالتكنولوجيا تجعل الأماكن إلكترونياً متجأورة . 2- تقليـص المـكان: حيـث تتيـح وســائل التخزيـن اسـتيعاب حجمـاً هائـلا

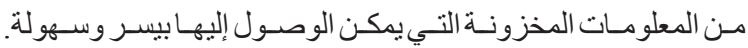
3- تقليص الوقت: حيـ أنـه مـع كل تطـور تكنولوجي سـيتناقص الوقت

$$
\text { المطللوب للاستجابة للطلبـات . }
$$

4- تز ايــ النظم الثـبكية: حيـث يمكن ربـط النظـم الداخليـة مـع بعضهـا

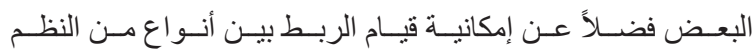

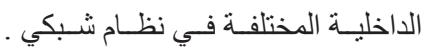

5- نطويـر البيئـة الإلكترونيـة فكريـاً: حيـ إن التفاعل لوقت طويـل مـع

نظـم المعلومـات يسـهم في تشكيل السـلوك الفكري للأفر اد.

\section{أسباب انتشار تكنولوجيا المعلومات}

هنـاك عدة أسباب ور اء الانتشـار الهائل لتكنولوجيـا المعلومـات في المنظمـات الانتاجيـة و الخدميـة على حد سو اءو وهي (Kronkie,2011): 1- زيـادة الانتاجيـة : و يقصــ بالانتاجيـة انتاجيـة المـوارد البشـرية الماديـة و الطبيعيـة كمـاً كيفـاً.

2- تحسـين الخدمـات: لعبـت التكنولوجيـا دوراً أساسـياً فـي تحسـين

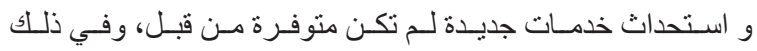
مجـالات عديــدة مـن أبرزهــــــــــات المصــارف، المو اصـلات،

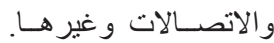
3- السيطرة على التعقيـد: أثبتت كل المعطيـات أن تكنولوجيـا المعلومـات

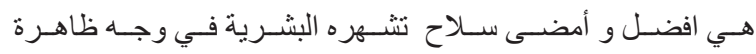
التعقيـد الثـديد الــي بـات يعتـري جميـع مظاهـرة الحيـاة الحديثـة.

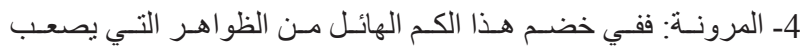

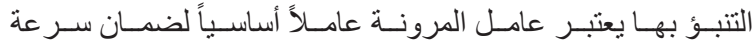

وبعبـارة أخـرى فـإن تكنولوجيـا المعلومــات تدعـم نظــام المعلومـات لتوفيـر معلومــات دقيقـهـه وكافيـة عـن الأنشـطة المختلفــة للمنظمــة مـن

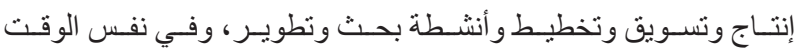
تكون قـادرة على تلبيـة حاجـات الإدارة مـن المعلومـات الخاصـة بالبيئسة

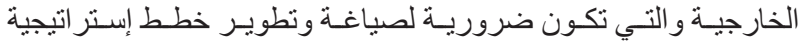
بعيدة الأجل، وكذلك خطط متوسطة وقصبرة الأجلـ وبمـا يحقق ميزة تنافسـبة لمنظمـات الأعمـال.

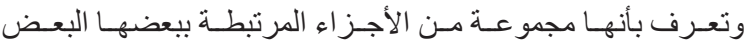
حيـث تشـتمل علـى أســاليب المعالجـة الســريعة للمعلومـات باسـتخدام الحاسـوب وتطبيـق الأسـاليب الإحصائيـة و الرياضيـة في حل المشكلات ومحـاكاة التفكيـر مـن خـلال بر امـج الحاسـوب ( الجاسـم، 2005). وهـي أيضـاً بأنهـا عبـارة عـن المكونــات الماديـة و البرمجيـات

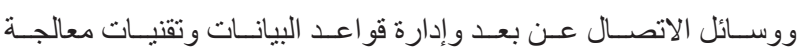

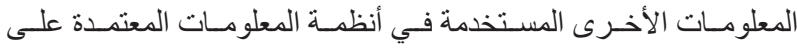
الحاسـوب (Laudon, 2014) ( ياسـين، 2010 ). وهـي بهـذا تختلــ عـن أنظهـة المعلومــات التـي تعـرف بأنهـا "مجموعـة مـن العناصـر المتر ابطــة (الماديـة، و البشـرية، و البرمجيـات، و البيانـات، الإجـر اءات) تعدـل علـى جمـع ومعالجـة وخـزن و اسـترجاع المعلومــات وتوزيعهــا بهـدف دعـم اتخــاذ القـر ار ات و السـيطرة داخـلـ المنظمـة، كمـا تسـاعد المديريـن و العامليـن فـي كسـب و ابتـكار معرفـة جديـدة، وحـل المشـكلات و إبـداع منتجـات وخدمـات وطر ائـق عمليـات جديـدة تسـهم فـي دعـم الميـزة التنافسـية ( Laudon, 2014$)$ ويـرى الباحــث أن تكنولوجيــا المعلومــات تـؤدي دوراً اسـتر اتيجياً في المنظمـة، مـن خـلال المسـاعدة في الخلق و الإبــاع، وتبـادل الأفكار و الآر اء، وسـرعة تطويـر منتجــات وخدمــات جديـدة، وجعلهـا أكثـر

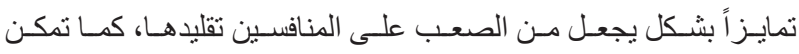

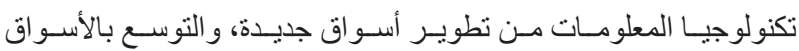
الحاليـة، وزيـادة كفـاءة العمليـات مـن خـلال خفض التكاليـف وتحسـين نو عيـة المنتجـات و الخدمـات المقدمـة للمسـتهلكين، و تسـتطيع المنظمــة أيضــاً مـن خلالهــا بنـاء تحالفـات اسـتر اتيجية لغـرض اكتسـاب معرفــة جديدة تعزز قدرتها التنافسية وموقعهـا في السـوق، كمـا تسـاعد في بنـاء مصـادر تكنولوجيـا معلومـات اسـتر اتيجية تسـنطيع المنظمـة مـن خلالهـا جمع المعلومـات الداخليـة و الخارجيـة بــا يمكنهـا مـن بنـاء قاعدة معرفيـة

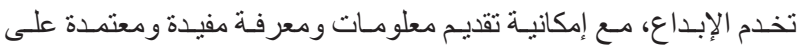

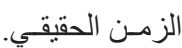

\section{مكونات تكنولوجيا المعلومـات} تتكـون تكنولوجيـا المعلومــات مـن أربـع تقنيـات فرعيـة هـي (اللامــي، 2010) 


\section{أنواع الميزة التنافسية}

للميزة التنافسية أنواع ومن أشهر ها (الزعبي، 2005):

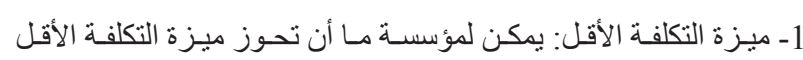

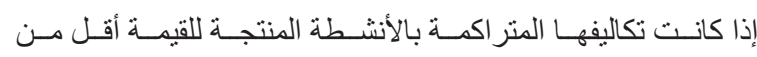

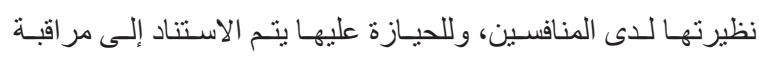

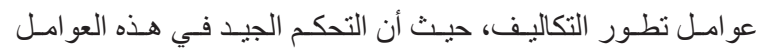

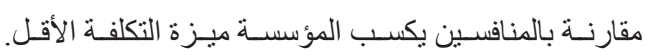

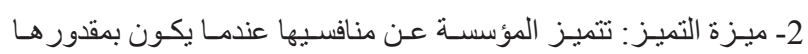

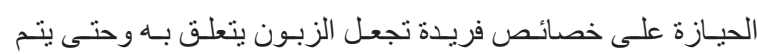

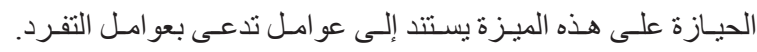
3- ميـزة التركيز : و هـي تحديد فئهـ أو طبقـة معينـة مـن السـوق و التركيز عليها وخدمتهـا بشكل مميز ومختلف وفئ عن المنافسـين.

\section{الار اساث السابقة}

دراســة (الخوالــدة، 2008) بعنــوان: "أنتـر اســتخدام تكنولوجيــا المعلومـات علـى الإبـــاع الاداري فـي المؤسســات العامـة الأردنيـة". هدفت هذه الدر اسـة للتعـرف إلى أثنر استخدام تكنولوجيـا المطلومات

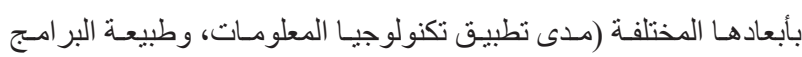

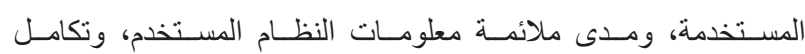

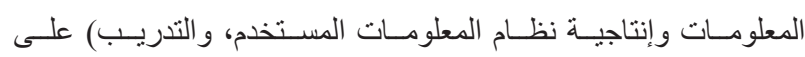

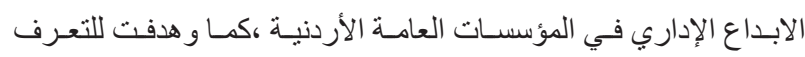

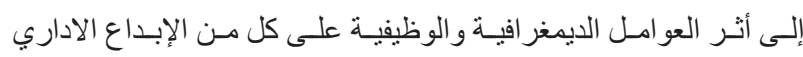
و اسـتخدام تكنولوجيـا المعلومسات فـي هـــه المؤسســات. وقد تكـون مجتمـع الدر اسـة مـن جميـع المؤسسـات العامـة المسـتقلة،

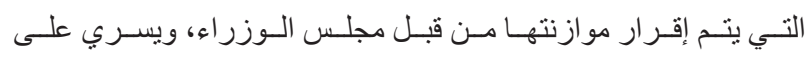
موظفيهـا نظـام الخدمـة المدنيـة الـذي يسـري إلى موظفـي الدولــة كافـة،

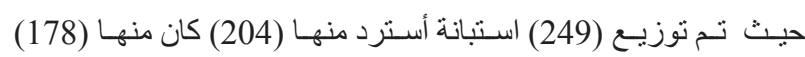

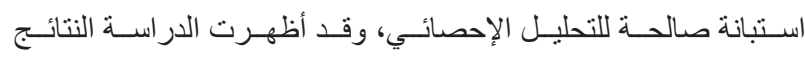

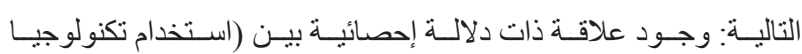
المعلومـات وطبيعـة البر امـج المستخدمة ومـدى ملائمسة معلومـات النظـام

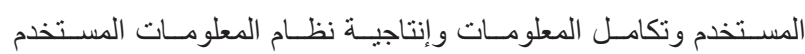
و التدريـب) و الإبـداع الإداري، وعـدم وجـود علاقـة ذات دلالــة احصائيـة

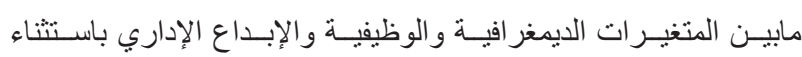

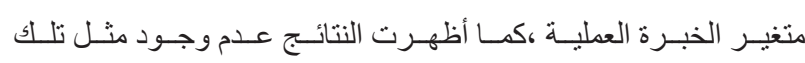
العلاقـة مابين هذه المتغير ات واستخدام تكنولوجيـا المعلومـات باستثناء متغيـر الجنس ولصالـح الذكـور. وأوصــت الدراســة بضـرورة تبنـي السياسـات الملائمسة و إعـداد

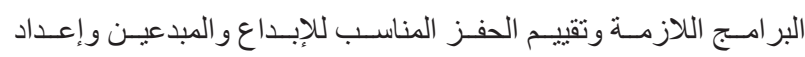

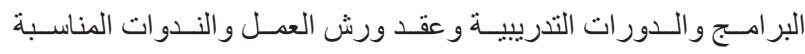
لمختلف المسـتويات الإداريـة حـول الطـرق الفعالـة للتعامـل مـع تكنولوجيا
تكيـف النظـم و تجأوبهـا مـن المتغيـر ات و المطالـب العديـدة.

\section{دور تكنولوجيا المعلومات في المنظمات}

دور تكنولوجيـا المعلومـات لا يقتصـر على الفعاليـات و البرمجيـات

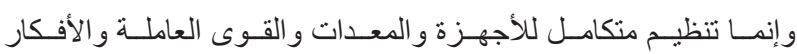

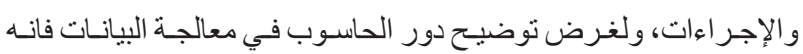
يتمثنل في المر احـل التاليـة ( Laudon, 2014 ):

1- مرحلـة جمـع البيانـات: وهـي عمليـة جمـع البيانـات مـن داخـل المنظمـة وخارجها، فالبيانـات التـي تكون مـن داخل المنظمـة هـي مـن نتائـج

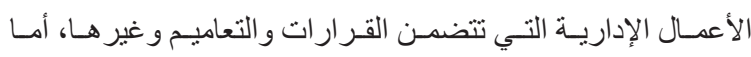

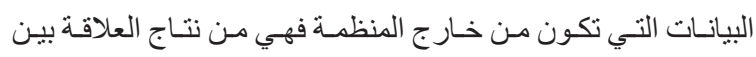

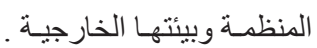
2- مرحلـة تنظيم البيانـات: وهي عمليـة تنظيم البيانـات الواردة وتصنيفها

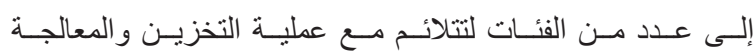
و الاسـتخدام. 3- مرحلـة معالجـة البيانـات: وهـي عمليـة تجـري على البيانـات الخـام

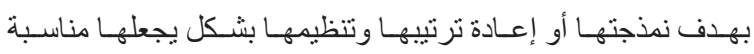

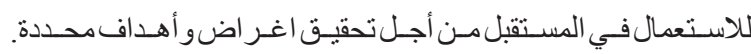
4- مرحلـة إنتـاج المعلومــات: وهـي عمليـة بثـرية لإنتـاج المعلومــات، كمـا إنهـا آليـة نظـر اً لمحدوديـة قدرة الانسـان على معالجـة طاقـات

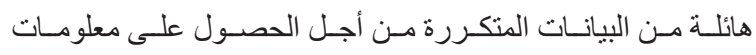
جديـدة وفعليـة للاسـتخدام عنـــ الحاجـة. 5- مرحلـة اسـتخدام المعلومـات: وهـي عمليـة استخدام الافر اد للمعلومـات التي تم الحصـول عليهـا أو جمعهـا مـن نظـام إدارة المعلومـات لأداء الأعمـال أو اتخـاذ القرار ات أو وضـع الفرضيـات، هذا وتعتبر وحدة تشـيل نظـام عمليـة الرقابـة هـي المستخدم النهائسي لهذه المعلومـات .

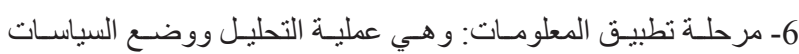
و إدارة المشـرو عات أو البر امـج و غيرهــا.

الميزة التنافسية

تعـرف القدرة التنافسـية بأنهـا المهـارة أو التقنيـة أو المـورد المتميـز

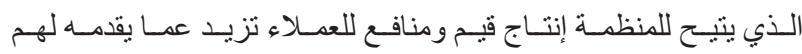
المنافسـون، ويؤكد تميز هـا و اختلافهـا عـن هـؤلاء المنافسـين مـن وجهـة

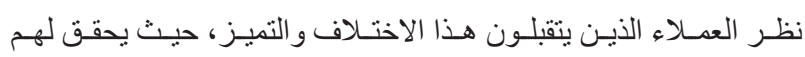

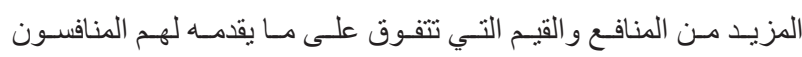

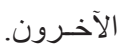

ويـرى(porter) أن الميـزة التنافسـية تنشـأ بمجـرد نوصـل المؤسســة

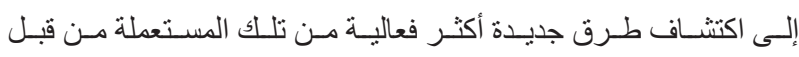

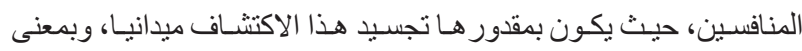
أخـر بمجـرد أحـداث عمليـة إبـداع بمفهومـهـ الواسـع (porter,2006). 
لتكنولوجيـا المعلومـات و الأهــاف الرئيسـية لتكنولوجيــا المعلومــات،

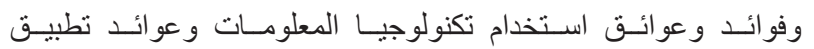

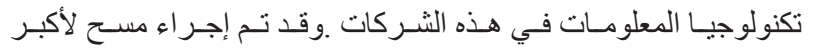

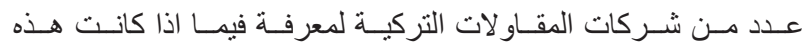
الثـركات تســخذم تكنولوجيـا المعلومــات فعليـا لتحقيـق ميـزة تنافسـية. وقد توصلـت الدر اسـة إلى أن تكنولوجيـا المعلومـات تسـتخدم غالبـا لـدى العامليـن في المسـتوى التشـيلي مـن أجلـ تحقيـق أثنر فنـي و اقتصــادي،

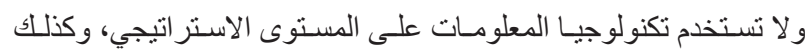

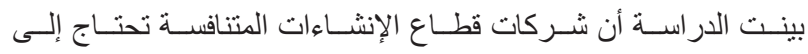
اســتخدام تكنولوجيــا المعلومــات علــى المسـتوى الاسـتر اتيجي لتحقيـق

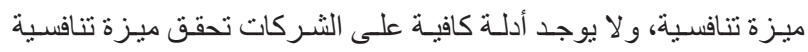

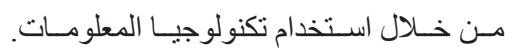
Impact of) بعنــوان (wang and others,2006) دراســــ Information technology on Competitive Advantage (in Third-party Logistics Firms,2006 وقــــ هدفـت الدراســة إلـى معرفـة العلاقــة بيـن تكنولوجيـا المعلومـات و الميـزة التنافسـية فـي الثـركات اللوجستية في الصين ،وقد توصلـت الدر اسـة إلى ان التركيز على تكنولوجيـا المعلومـات يؤثر وبدلالـة إحصائيـة على الميزة التنافسية فـي الثــركات اللوجسـتية، وان هــا التأثيـر ليـس خطبـاً. در اسة (Bin Ismail and ong,2008) بعنوان: Sustainable Competitive Advantage through Information Technology Competence: Resource-Based .View on Small and Medium Enterprises

هدفـت هـــه الدراسـة إلـى التعـرف إلـى واقـع الميـزة التنافسـية

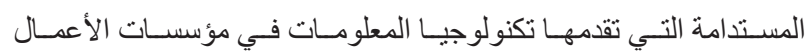
الصغيـرة و المتوسـطة الحجـم فـي ماليزيـا، حيـث أكـدت أن تكنولوجيــا

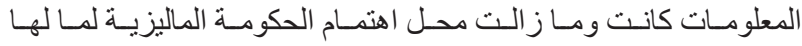
مـن قدرة على ثقويـة دعائسم الثـركة الصغيـرة والمتوسطة الحجـم في

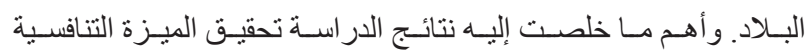
المسـتـامة مـن خـلال بنـاء قـدر ات تكنولوجيــا المعلومـات بيـن العو امـل البشـرية و التســـيلات التكنولوجيـة داخـل المؤسســة. و أكـدت الدر اســة على ضـــرورة امتـلاكك مسـتخدم التكنولوجيـا المعرفـة العلميـة و التطبيقيـة

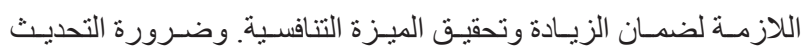
المسـتمر لوسـائل اسـتخدام تكنولوجيـا المعلومـات وتحديثهـا لأنهـا تتغيـر

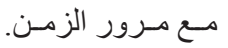
وفي در اسة (Daneshvar , 2010) بعنوان : Review Of Information Technology Effect On" Competitive Advantage- Strategic Perspective هدفت إلى مر اجعـة أثـر تكنولوجيـا المعلومـات على الميـزة التنافسـية
المعلومـات. ومر اعـاة العنصـر البشـري عند الاختيـار و التعيين مـن حيث

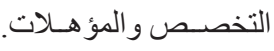

دراسـة الثــرفا (2008) بعنـوان "دور إدارة المعرفة و تكنولوجيا المعلومات في تحقيق المزايا التنافسية في المصارف العاملة في قطاع غزة"، هدفت الدراسة إلى التعرف إلـى دور إدارة المعرفة و تكنولوجيا المعلومات في تحقيق المز ايا التنافسية في المصارف العاملة في قطاع غزة. وقد جرى تطبيق المنهج الوصفي التحليلي في هـــه الدراسة باستخدام استبانه تم توزيعها على جميع المديريـن العامين ورؤساء الأقسام في المصارف المبحوثة، و عددهــم (174) موظةًا وتوصلت الدراسة إلى مجموعة من النتائج أهمها: - ان

1- تطبق المصارف العاملة في قطاع غزة نظام تكنولوجيـا إدارة المعرفـة في جميع الوحدات والأقسام، وتحرص على ضرورة الاستفادة من استخدامات تكنولوجيـا المعلومـات والاتصالات والاستفادة من المهارات والخبرات المتوفرة لديها واستثمار الكوادر البشرية ومعارفهم في مجال التنمية والنهضة لتصل إلى مستوى التعايش و التو اصل مع العالم المحيط ومو اكبة التطــور ات المتلاحقة في ظـلـ تكنولوجيا المعلومات المتقدمة. 2- أظهرت نتائج الدر اسة عدم وجود وحدة تنظيميـة أو قسم خـاص لإدارة المعرفـة و تكنولوجيا المعلومات داخل أي مصرف في قطاع غزة إلا أنه يتم تطبيق نظــم إدارة المعرفـة و تكنولوجيا المعلومات داخل

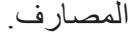

3- توجد علاقة ذات دلالة إحصائية بين إدارة المعرفة و تكنولوجيا المعلومـات ومجـالات الميزة التنافسية ( جودة المنتجات، الأداء المالي، السيطرة على الأسـواق، كفـاءة العطليـات، الإبداعو التطوير) عند مستوى دلالة $0.05=0$. و قد خرجت الدر اسة بعدة توصيات أهمها ما يلي : 1- تعميق وعي و إدراك المسئولين في المصارف للتحديات الكبيرة و المعوقات المستمرة و المنافسة الثديدة التي يو اجهها القطاع المصرفي في قطاع غزة حاضر اً و مستقبلا . 2- ضرورة أن يولي المسئولون في القطاع المصرفي في قطاع غزة اهتمامـا زائدا لإدارة المعرفة و العمل على إنشاء إدارة متخصصة لإدارة المعرفة و تكنولوجيا المعلومات.

وفـي دراسـة (cakmak and tas,2012) بعنـوان The Use) of Information Technology on Gaining Competitive Advantage in Turkish Contractor Firms) Competitive (Advantage in Turkish Contractor Firms معرفـة مـدى اســخدام تكنولوجيــا المعلومــات فـي شـركات المقــاو لات التركيـة وأهيـة اسـتخدام تكنولوجيـا المعلومـات علـى المسـتوى الاسـتر اتيجي لتحقيـق الميـزة التنافسية، وقد تـم بحـث الاسـتخدام الحالي 
المتغيرات الايمغرافية

الجدول (2) يبين المتغيرات الثخصية و الوظيفية لعينة الدر اسة:

جدول 2. المتغير ات الثخصية والوظيفية لعينة الدراسة (186)

\begin{tabular}{|c|c|c|c|}
\hline المتغير & المستوى & التكر ار & النسبة \\
\hline \multirow{2}{*}{ الجنس } & ذكر & 118 & $63 \%$ \\
\hline & انثى & 68 & $37 \%$ \\
\hline \multirow{3}{*}{ المؤهل العلمي } & دبلوم فاقل & 44 & $24 \%$ \\
\hline & بكالوريوس & 86 & $46 \%$ \\
\hline & در اسات عليا & 56 & $30 \%$ \\
\hline \multirow{4}{*}{ مدة الخدمة } & أقل من 5 سنوات & 20 & $10 \%$ \\
\hline & من -5 10 سنوات & 60 & $33 \%$ \\
\hline & من 10 إلى 15 سنة & 84 & $45 \%$ \\
\hline & أكثر من 15 سنة & 22 & $12 \%$ \\
\hline \multirow{3}{*}{ العمر } & أقل من 25 سنة & 84 & $46 \%$ \\
\hline & دن 35-25 سنة & 58 & $31 \%$ \\
\hline & أكثر من 35 سنة & 44 & $23 \%$ \\
\hline \multirow{3}{*}{ الوظيفي } & مدير & 84 & $46 \%$ \\
\hline & رئيس قسم & 58 & $31 \%$ \\
\hline & موظف & 44 & $23 \%$ \\
\hline
\end{tabular}

مستوى توفر أبعاد (متغيرات) الدراسة

المحور الأول: تكنولوجيا المعلومات (المتغير المستقل)

جدول 3. المتوسطات الحسابية و الانحر افات المعيارية والرتب

\begin{tabular}{|c|c|c|c|c|}
\hline الرقم & نص الفقرة & الحسابي & الانحراف الفياري & الرتبة \\
\hline 1 & 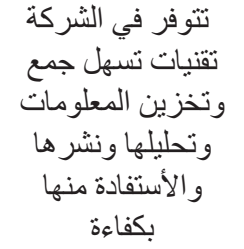 & 4.2667 & 82768. & الأولى \\
\hline 2 & التخضع الافر اد إلى التى التكريب في استخدام & 4.2333 & 67891. & الثانية \\
\hline 3 & تكنولوجيا المعلومات الشركة & 4.1333 & 73030. & الثالثة \\
\hline 4 & 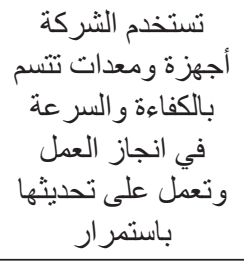 & 4.0667 & 78492. & الر ابعة \\
\hline 5 & و الثعدات المستخف التقنيات باتمة & 3.8000 & 1.09545 & الخامسة \\
\hline
\end{tabular}

مـن منظـور اسـتر اتيجي، حيـث أكـدت على الـدور البـارز لتكنولوجيـا

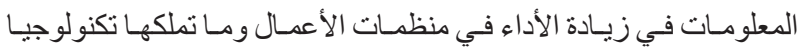
المعلومــات مـن فو ائــــ وآثـار إيجابيـة في ديمومـة العمـل وتطويـره. وخلصــت الدر اســة إلـى أن تكنولوجيـا المعلومــات تســخدم ضــن سلسـلة النشـاطات المؤسسـاتية التـي تضهـن سيطرة أفضـل على الوظائف والعمليـات وتسـهيل عمليـات صنـع القـرار، و أصبحـت تكنولوجيـا

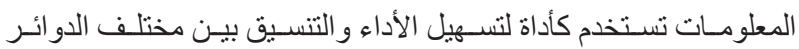

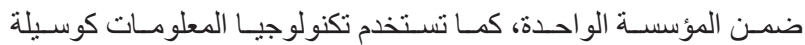
اسـتر اتيجية تنافسـية. ثالثاً: التحليل الإحصائي ومناقشة التتائج ثبات أداة الاراسة لاختبار ثبات أداة الدر اسة تم قياس: أـ صدق الأداة (Instrument Validity): وهي عمليـة التأكـد مـن أن الفقـرات التـي تحتويهـا الاسـتبانة تـؤدي

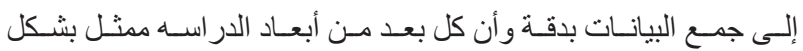

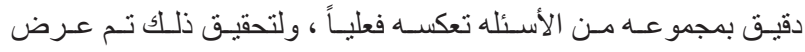
الاسـتبانة على مجموعـة مـن الاسـاتذة المتخصصيـن، كمـا تـم ذكـره

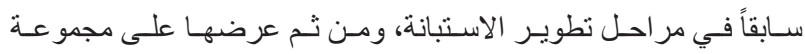
مـن مديـري الوحدات في المنظمـات عينـة الدر اسـة وبلــغ عددهـ سبعة، وذلـك للتأكـد و التعـرف الـى مـدى فهم العبـار ات و الكلمـات المسـتخدمة

$$
\text { ودرجـة وضوحهـا وسـهولتها. }
$$

ب- ثبات الاداة (Instrument Reliability):

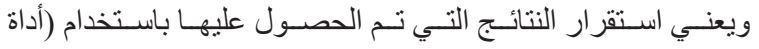
القيـاس) عـدة مـر ات، فهو يشـير وباختصــار إلى عـدم تعـرض النتائسج للتغييـر مـع ظـروف القيـاس، وقـد تـم احتسـاب ذلـك مـن خـلال معامـل الاتسـاق الداخلي كرونبـاخ الفـا (Cronback-Alpha) لعشرين فرداً تم

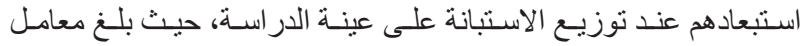
كرونبـاخ الداخلـي ككل لجميـع فقـرات الاسـنبانة (83\%) و هـي نسـبة عاليـة وتؤكد بالطبـع مدى صحسة وصدوق الاستبانة، وهي نسبة ممتـازة كونهـا أعلى مـن النسبة المقبولـة (60\%) (Sekran,1992 ), ويوضـح الجدول (1) معامـل الثبـات لـكل مجـال مـن مجـالات الدر اســة.

جدول 1. معامل الإتساق الداخلي كرونباخ الفا

\begin{tabular}{|c|c|c|}
\hline & كرونباخ الفات الإخلي & عدد الفقر ات \\
\hline المجال الأول & 0.82 & 8 \\
\hline المجال الثاني & 0.85 & 19 \\
\hline المجالات مجتمعة & 0.83 & 27 \\
\hline
\end{tabular}




\begin{tabular}{|c|c|c|c|c|}
\hline 3 & تقديم منتجاتها الثركة إلىى & 3.8000 & 88668. & الثالثة \\
\hline 4 & 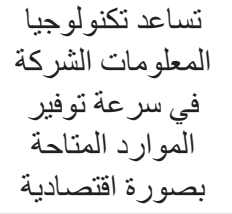 & 3.6333 & 1.03335 & الر ابعة \\
\hline 5 & التركز الثركة على التطوير & 3.5512 & 0.9871 & الخامسة \\
\hline & المجموع & 3.723 & 0.9892 & \\
\hline
\end{tabular}

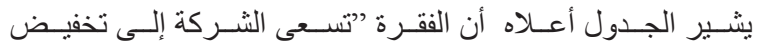

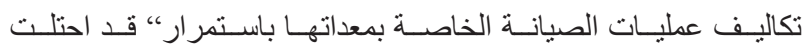
المرتبـة الأولـى بوسـط حسـابي (3.8) و انحــر اف معيـاري (0.91)

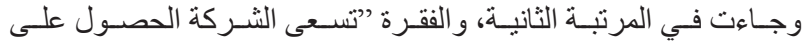
حصـة ســوقية اكبـر لتحقيـق نجاحهـا وتفوقهـا "بوســـ حسـابي (3.8) و انحـر اف معيـاري (1.12) وجـاءت في المرتبـة الأخيـرة الفقرة "تركز

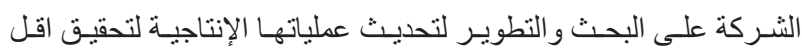
كلفة "بوسط حسـابي (3.55) قد بلــغ و انحـر اف معيـاري (0.98)، وبلـغ الوســـ الحســي للمجـال ككل (3.72) و الانحــر اف المعيـاري (0.98).

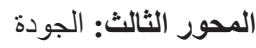

جدول 5. المتوسطات الحسابية و الانحر افات المعبارية و الرتب

\begin{tabular}{|c|c|c|c|c|}
\hline الرقم & نص الفقرة & الحسابي & الانحر افياري & الرنبة \\
\hline 1 & الصضميم العمليات الانتاجية يحقق مستوى من & 4.1000 & 99481. & الأولى \\
\hline 2 & تقديم منتجات تتلاءم احتيات الزبأن & 3.9667 & 76489. & الثانية \\
\hline 3 & تلى استخدام التكنولواليب أسيا & 3.7333 & 69149. & الثالثة \\
\hline 4 & طرق متعددة للرقابة الشركة & 3.7000 & 1.29055 & الر ابعة \\
\hline & المجموع & 3.875 & 0.935435 & \\
\hline
\end{tabular}

يبيـن الجـدول (5) أن الفقـرة ”تصميــم العمليـات الإنتاجيـة يحقـق

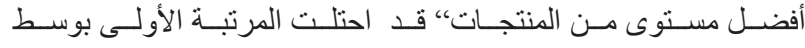
حسـبي (4.1) و انحـر اف معيـاري (0.99) وجـاءت فـي المرتبـة الثانيـة

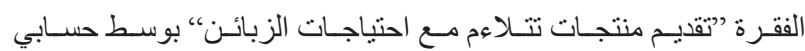

\begin{tabular}{|c|c|c|c|c|}
\hline 6 & الموجنبر البردة في الثركة & 3.7667 & 1.13512 & السادسة \\
\hline 7 & 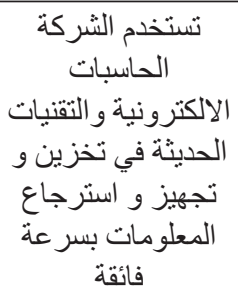 & 3.7667 & 1.10433 & السابعة \\
\hline 8 & شتبكات اتصال شتر فعالة & 3.6667 & 88409. & الثامنة \\
\hline & المجموع & 3.962 & 0.9051 & \\
\hline
\end{tabular}

يظهـر مـن الجـدول أعـلاه أن الفـرة ” تتوفـر فـي الثــركة تقنيـات تســـل جمـع و تخزيـن المعلومـات وتحليلهــا ونشـر ها والاسـتفادة منهــا

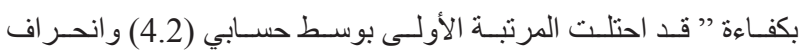
معيـاري (0.82) وجـاءت فـي المرتبــة الثانيــة الفقـرة "يخضـــع الأفـراد إلى التدريبـ و التطويـر في استـخدام التكنولوجيـا"، بوسط حسـابي (4.2) و اندـر اف معيـاري (0.67) وتلتهــا في المرتبـة الثالثـة الفقرة ”تسـتخدم الشـركة تكنولوجيـا المعلومـات "بوسط حسـابي (4.1) و انحـر اف معيـاري (0.73) وجـاءت في المرتبـة الأخيـرة الفقرة ”تســتخدم الشـركة شـبكات اتصــال فعالــة " بوســط حسـابي (3.66) انحــر اف معيـاري ( 0.88.)

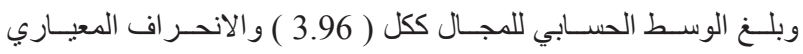

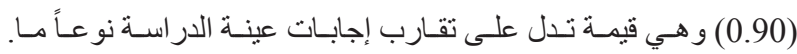
و هذا بـدل وبشـل و اضـح ان تكنولوجيـا المعلومـات متوفرة ومسـتخدمة بدرجـة عاليـة في المؤسسـات المبحوثـة وهذا مؤشـر على حـرص هـذه المؤسسـات لاستخدام تكنولوجيـا المعلو مـات و الاسـفـادة منهـا. و تتفق هذه

BinIsmail and ong, (النتيجـة مـع در اسـة ( الثــرفا، 2008) ودر اســـة (2008

المحور الثاني: التكلفة

جدول 4. المتوسطات الحسابية و الانحر افات المعيارية و الرتب

\begin{tabular}{|c|c|c|c|c|}
\hline الرقم & نص الفقرة & الحتوسطي & الانعراف افي & الرتبة \\
\hline 1 & تشعىى الثركة إلى تكاليف & 3.8333 & 91287. & الأولى \\
\hline 2 & سلحوقية اكبر لتى لتحقيق الثركة & 3.8000 & 1.12648 & الثانية \\
\hline
\end{tabular}




\begin{tabular}{|c|c|c|c|c|}
\hline 1 & تسليم طلبات الزبائن & 4.0000 & 94686. & الأولى \\
\hline 2 & المنتجات الجديدة فتديم & 3.5000 & 1.27982 & الثانية \\
\hline & المجموع & 3.75 & 1.1133 & \\
\hline
\end{tabular}

يتبيـن مـن الجـدول أعــلاه أن الفقـرة ” تسـليم طلبـات الزبائسن في

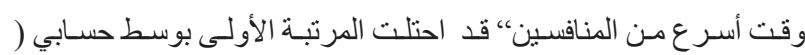
4.00) و انحر اف معيـاري (0.94) وجـاءت في المرتبـة الأخيرة الفقرة

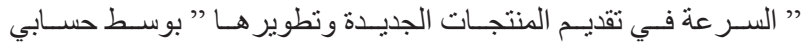
(3.5) قد بلـنغ و انحـر اف معيـاري (1.2 )، وبــنغ الوسط الحسـابي للمجـال ككل ( 3.75 ) و الانحر اف المعيـاري ( 1.11). وهذا مؤشر على التزام الثـركات ---- التشـليم و اهتمامهـا بتطويـر خدماتهـا.

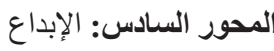

جدول 8. المتوسطات الحسابية و الانحر افات المعيارية و الرتب.

\begin{tabular}{|c|c|c|c|c|}
\hline الرقم & نص الفقرة & الحسابي & الانحر افياري & الرتبة \\
\hline 1 & وطرق النتاج وتوزيع أساليب & 4.214 & 1.241 & الأولى \\
\hline 2 & قورة الثركة المنافسة على & 3.874 & 0.9874 & الثانية \\
\hline 3 & 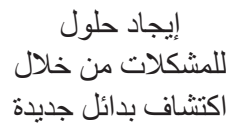 & 3.785 & 0.7854 & الثالثة \\
\hline 4 & 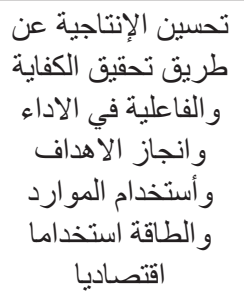 & 3.614 & 1.321 & الر ابعة \\
\hline & المجموع & 3.8717 & 1.083 & \\
\hline
\end{tabular}

يظهر مـن الجدول أعـلاه أن الفقرة ”تطويـر أسـاليب وطـرق إنتـاج

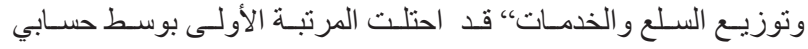
( 4.2 ) وانحـر اف معيـاري (1.24 ) وجـاءت في المرتبـة الثانيـة الفقرة

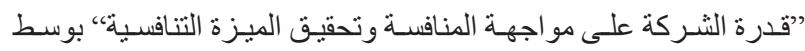
حسـابي (3.87) و انحــر اف معيــاري (0.98)، وجـاءت فـي المرتبـة الأخيـرة الفقرة،، تحسـين الإنتاجيـة عـن طريـق تحقيـق الكفايـة و الفاعليـة فـي الأداء و إنجـاز الأهـداف واســتخدام المـوارد والطاقـة اسـتخدامـا اقتصاديـا، بوسط حسـابي (3.61 ) قد بلـغ و انحـر اف معيـاري (1.32)، وبـــغ الوســ الحسـابي للمجـال ككل (3.87 ) و الانحـر اف المعيـاري (

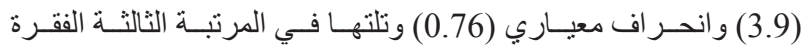

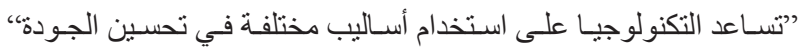
بوسط حسـابي (3.7) و انحـر اف معيـاري (0.69). وجـاءت في المرتبـة

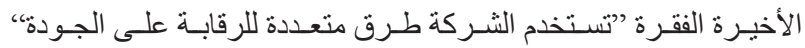
بوسط حسـابي (3.7) قد بلـنغ و انحر اف معيـاري (1.29). وبلـغ الوسط الحسـبـي للمجـال ككل (3.87) و الانحـر اف المعيـاري (0.93). و هذا يـل على ان المؤسسـات فعـلاً تحـاول تخفيض كلف عملياتهـا وتقديم خدماتهـا بأسـعار أقـل وتسـتخدم تكنولوجيـا المعلومــات في تحقيـق ذلـك.

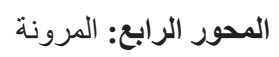

جدول 6. المتوسطات الحسابية والانحر افات المعيارية والرتب.

\begin{tabular}{|c|c|c|c|c|}
\hline الرقم & نص الفقرة & الحسابي & الانحر افياري & الرتبة \\
\hline 1 & يمتلك العاملون في & 4.0000 & 94686. & الأولى \\
\hline 2 & 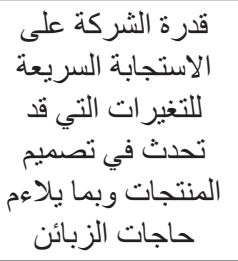 & 3.7333 & 1.01483 & الثانية \\
\hline 3 & 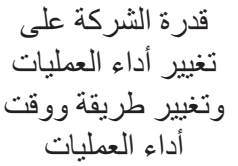 & 3.7000 & 95231. & الثالثة \\
\hline 4 & قدرة العمليات على أو منتجات جديدة & 3.547 & 1.321 & الر ابعة \\
\hline & المجموع & 3.7450 & 1.0587 & \\
\hline
\end{tabular}

يظهـر مـن الجـدول (6) أعـلاه أن الفقـرة ”يمتلـــك العاملـون فـي

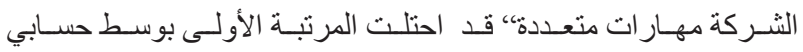
(4) و انحــر اف معيـاري( 0.94) وجـاءت فـي المرتبـة الثانيــة الفقـرة

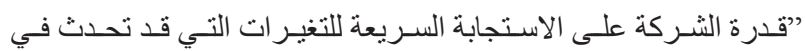
تصميـم المنتجـات وبمـا يـلاءم حاجـات الزبائنن، بوسـط حســـي (3.7 ) و انحـر اف معيـاري (1.01) وجـاءت في المرتبـة الأخيرة الفقرة ” قدرة العمليـات على تقديم منتجـات جديدة أو معدلـة"، بوسط حسـابي (3.7) قد

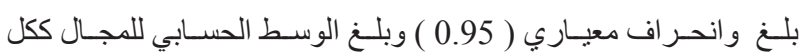
(3.74) و الانحـر اف المعيـاري (1.05). و وهـا يبيـن ان الثـرفات لديهـا القدرة على التكيف مـع الظـروف البيائيـة المحيطـة و الاستجابة للتغيـرات بدرجـة عاليـة. المحور الخامس: التسليم جدول 7. المتوسطات الحسابية و الانحر افات المعيارية و الرتب

\begin{tabular}{|c|c|c|c|}
\hline الرقم & نص الفقرة & الحستبي & الانحرياف \\
\hline
\end{tabular}


جدول 11. نتائُج تطبيـق اختبـار (One Sample T-test) على مجـال

\begin{tabular}{|c|c|c|c|c|c|}
\hline & \multicolumn{5}{|c|}{ تكنولوجيـا المعلومــات و الجــودة } \\
\hline 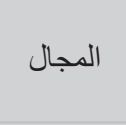 & الحسابي & الانحر افياري & قيمة & درجات & $\begin{array}{l}\text { المعنوية } \\
\text { Sig }\end{array}$ \\
\hline تكلولوجات & 4.15 & 0.57 & 24.25 & 143 & 0.000 \\
\hline
\end{tabular}

1.083). و هــا يـدل علـى اهتـــام الثـركات في ايجـاد و ابتكار طـرق جديـدة لتقديـم خدماتهـا و الاهتمـام بتحقيـق الكفـاءة و الفاعليـة للبقـاء وفي

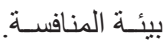

اختبار فرضية الارتباط

جـدول 9. يييـن نتائسج اختبـار الفرضيــة الرئيسـة الأولـى فرضيــة الارتبـاط و الفرضيــات الفرعيـة المنبثقــة عنهــا:

جذول 9. مصفوفة الارتباط للمتغيرات

\begin{tabular}{|c|c|c|c|c|c|c|c|}
\hline الميزة التنافسية تكنولوجيا المعلومات & & الكلفه & الجودة & 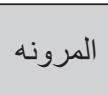 & 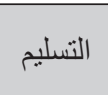 & الإبداع & التنافسية \\
\hline \multirow[b]{2}{*}{ تكنولوجيا المعلومات } & الارتباط معامل & $* * 370$ & $* * 242$ & $* * 467$ & $* * 600$ & $* * 420$ & $* * 410$ \\
\hline & الإحصائية & 000. & 000 . & 000 . & 000 . & 000. & 000. \\
\hline
\end{tabular}

يبين الجدول رقم (11 ) نتائج اختبـار (T) للفرضيـة الفرعبـة الثانية،

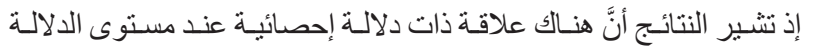

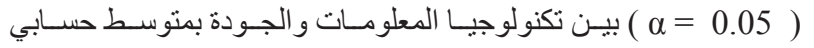
(4.15) أبي بنسبة (83\%)، وان مسـتوى المعنويـة (0.00) و هـي أقل مـن مسـتوى الدلالــة الإحصائيـة(T)

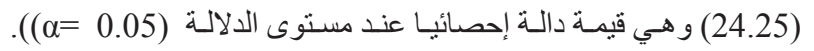

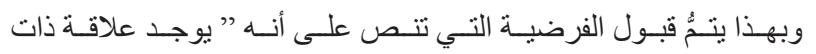

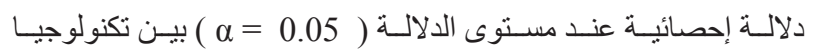

$$
\text { المعلومـات و الجـودة. }
$$

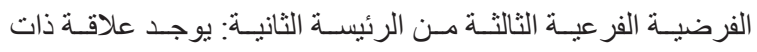

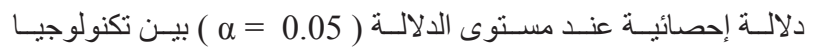
المعلومـات و المرونة.وهـــا يتفـق مـع در اســة ( الثـرفاء، 2008 ). الجـدول ( 12 ) نتائـج اختبـار (One Sample -T.test) لمجــال تكنولوجيـا المعلومــات و المرونـــة

\begin{tabular}{|c|c|c|c|c|c|}
\hline المجال & الحستبي & الانحر اف المعياري & قيمة & الحرية & $\begin{array}{c}\text { المعنوية } \\
\text { Sig }\end{array}$ \\
\hline تكنولوجيات المعات & 4.15 & 0.64 & 21.54 & 143 & 0.000 \\
\hline
\end{tabular}

يشـير الجدول (12 ) نتائج اختبـار (ت) للفرضيـة الثالثـة، إذ نشـير

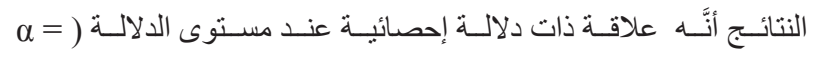
0.05) بين تكنولوجيـا المعلومـات و المرونـة بمتوسط حسـبي (4.15) أبي بنسـبة (83\%)، وان مسـتوي المعنويــة (0.00) وهـي أقـل مـن مسـتوى

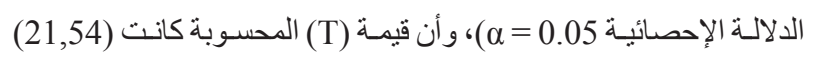

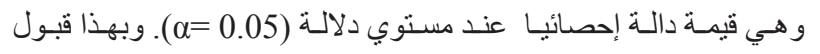

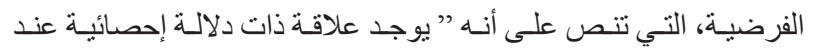

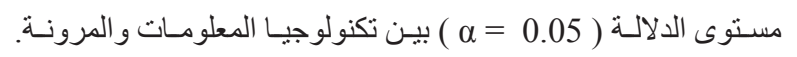

يثـير الجـدول (9) إلـى وجـود علاقـة ايجابيـة دالــة إحصائيـاً بيـن تكنولوجيـا المعلومـات و الميـزة التنافسـية بابعادهــا المختلفــة (التكلفـة، الجـودة ،المرونـة، التسـليم ،الإبــاع) بلغنـت (0.370، 0.2420، .0467، 0.600، 0.420) علـى التو الـي، وبيـن تكنولوجيــا المعلومسـات و الميـزة

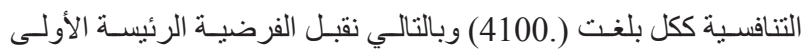
و التـي تثـير إلـى وجـود علاقـة ذات دلالــة إحصائيــة بيـن تكنولوجيــا المعلومــات و الميـزة التنافسـية و الفرضيـات المنبثقــة عنهـا وهـــا يمهـد

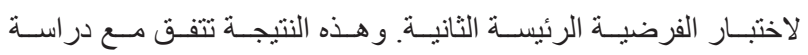

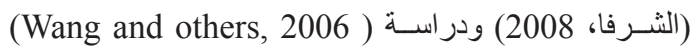

\section{اختبار الفرضية الرئيسة الثانية (فرضية الأثر)}

الجـداول (14-10) تبيـن نتائسج اختبـار الفرضيـة الرئيسـة الثانيــة

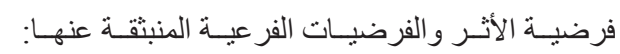

الجدول ( One Sample T-test) 10 ) نتائج تطبيـق اختبـار

مجـال تكنولوجيـا المعلومـات و التكلفـة

\begin{tabular}{|c|c|c|c|c|c|}
\hline المجال & الحسابي & الانحبراف & قيمة & درجات الحرية & 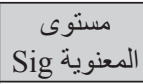 \\
\hline الكنولوجيات & 3.97 & 0.55 & 21.04 & 93 & 0.000 \\
\hline
\end{tabular}

قيمة (T) الجدولية (1.96)

يبين الجدول (10) نتائج اختبـار (ت) للفرضيـة الفرعيـة الأولى، إذ

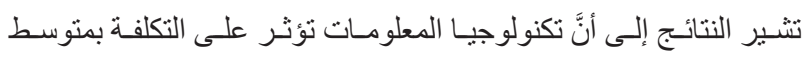
حسـابي (3.97) أي بنسـبة (79.4\%)، وان مسـتوى المعنويــة (0.00)

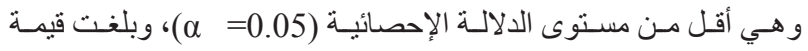
(ت) المحسـوبة لمجـال تكنولوجيـا المعلومـات (21.04) وهـي قيمـة دالـة

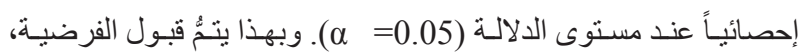

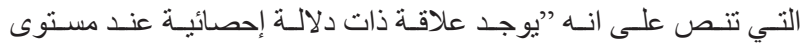
الالالــة ( $0.05=0$. 


\section{نتائج اختبار الفرضية الرئيسية الثالثة}

جدول 15. تبيـن نتائجج اختبـار الفرضيـة الرئيسـة الثالثة التـي تنص

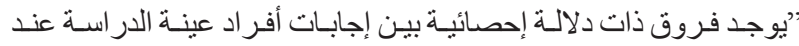
مسـتوى الدلالـة ( 0.05 ) لتطبيـق مجـال تكنولوجيـا المعلومـات تعـزى

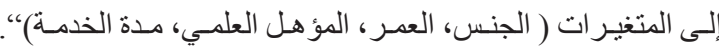
جـدول 15. المتوسـطات الحسـابية و الانحر افـات المعياريـة لمجـال تكنولوجيـا المعلومسات تبعـاً للمتغيـرات الثــخصية

\begin{tabular}{|c|c|c|c|}
\hline المتغير & المستوى & الحسابي & الانحريافي \\
\hline \multirow{2}{*}{ الجنس } & ذكر & 4.06 & 0.59 \\
\hline & أنثى & 3.88 & 0.77 \\
\hline \multirow{3}{*}{ المؤهل العلمي } & دبلوم فاقل & 3.87 & 0.25 \\
\hline & بكالوريوس & 3.85 & 0.58 \\
\hline & در اسات عليا & 4.22 & 330. \\
\hline \multirow{4}{*}{ مدة الخدمة } & اقل من 5 سنوات & 4.57 & 0.23 \\
\hline & من -5 10 سنو ات & 3.69 & 0.86 \\
\hline & من 10 إلى 15 سنة & 4.06 & 490. \\
\hline & اكثر من 15 سنة & 4.11 & 480. \\
\hline \multirow{3}{*}{ العمر } & اقل من 25 سنة & 4.07 & 520. \\
\hline & من 35-25 سنة & 3.63 & 490. \\
\hline & اكثر من 35 سنة & 3.88 & 610. \\
\hline \multirow{3}{*}{ المسمى الوظبفي } & مدبر & 3.95 & 320. \\
\hline & رئيس قسم & 3.94 & 600. \\
\hline & موظف & 4.05 & 690. \\
\hline
\end{tabular}

يظهـر مـن جـدول (15) وجـود فـروق ظاهريـة بيـن المتوسـطات الحسـابية للمجـالات تبعـاً للمتغيـر ات الثـخصية، حيـث كانـت في متغيـر الجنس لصـالـح الذكـور (4.06)، وفـي متغيـر المؤهـل العلمـي لصـالـح الدر اسـات العليـا بوسط حسـابي (4.22)، وفي متغير مدة الخدمـة لصـالح أقـل مـن 5 سـنوات بوسط حسـابي (4.57)، ولمتغيـر العمر لصـالـح أقـل مـن 25 بوسط حسـابي (4.07)، وفي المسـى الوظيفي لصالح موظف

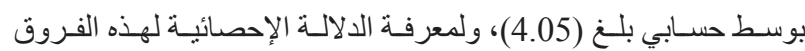
تـم تطبيـق تحليـل التبايـن المتعدد على كل مجـال مـن مجـالات الدر اسـة

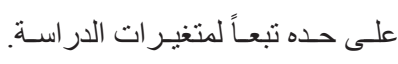
جدول 16. نتائـج تطبيـق تحليـل التبايـن المتعـد على مجـال تكنولوجيـا المعلومــات تبعـاً لمتغيـر ات الدر اســة

\begin{tabular}{|c|c|c|c|c|c|}
\hline المتغير & المربعاتع & الحرجاتة & المربعات & $\mathrm{F}$ & الإحصائية \\
\hline الجنس & 6.22 & 3 & 2.07 & 11.75 & 000 \\
\hline العؤهي & 760. & 3 & 250. & 1.43 & 230. \\
\hline مدة الخدمة & 780. & 4 & 190. & 1.11 & 350. \\
\hline العمر & 830. & 3 & 270. & 1.58 & 190. \\
\hline الوظيفي & 3.66 & 5 & 730. & 4.14 & 000. \\
\hline الخطأَ & 20.31 & 115 & 170. & & \\
\hline المجموع & 2408.57 & 144 & & & \\
\hline
\end{tabular}

الفرضيـة الفر عيـة الر ابعــة مـن الرئيســة الثانيـة: يوجـد علاقـة ذات

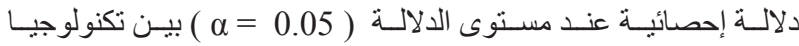

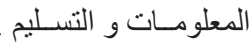

جـدول 13. نتائسج اختبـار (One Sample -T.test) بيـن تكنولوجيـا

\begin{tabular}{|c|c|c|c|c|c|}
\hline & & \multicolumn{4}{|c|}{ المعلو مــات و التســليم } \\
\hline المجال & الحسابي & الانعياري اف & قيمة & الحرجاتة & $\begin{array}{c}\text { المعنوية } \\
\text { Sig } \\
\text { Sig }\end{array}$ \\
\hline تكلولوجيا & 4.10 & 0.52 & 25.36 & 143 & 0.000 \\
\hline
\end{tabular}

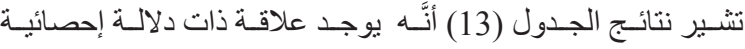

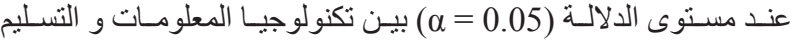
بمتوسط حسـبي (4.10) أي بنسبة (82\%)، ويظهر مـن جدول (13) ان قيمـة (T) بلغت (25.36) و هـي قيمـة دالـة إحصائيـا عند مستوب الدلالـة

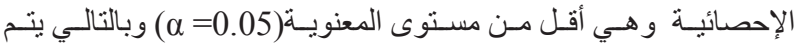

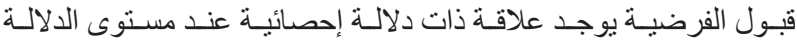
ب=0.05) الفرضيـة الفر عيـة الخامسـة مـن الرئيسـة الثانيـة: يوجــــــاقــة ذات

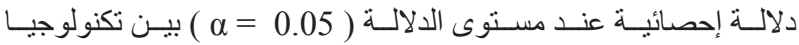
المعلومـات و الإبـداع.

جدول 14. نتائسج تطبيـق اختبـار (One sample T-test) على مجـال تكنولوجيـا المعلومـات و الإبـداع

\begin{tabular}{|c|c|c|c|c|c|}
\hline المجال & الحسابي & الانعياري اف & قيمة & درجات & $\begin{array}{c}\text { المعنوية } \\
\text { Sig }\end{array}$ \\
\hline تكنولوجيا & 3.42 & 0.63 & 7.87 & 143 & 0.000 \\
\hline
\end{tabular}

يبين الجدول (14 ) نتائهج اختبـار (T) للفرضيـة الخامسـة، إذ تشير

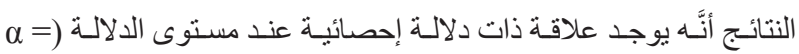
0.05 ) بيـن تكنولوجيـا المعلومـات و الإبـداع بمتوسـط حسـابي (3.42) أي بنسـبة (68.4\%)، وان مسـتوى المعنويــة (0.00) وهـي أقـلـ مـن

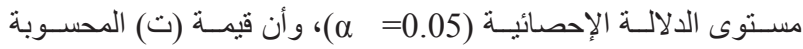

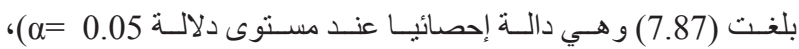

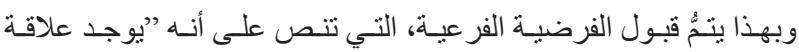
ذات دلالـة إحصائيـة عند مسـتوى الدلالـة ( 0.05 = م ) بيـن تكنولوجيـا

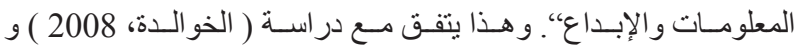

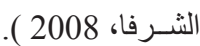

يثــير الجـول (14) إلى وجـود تأثيـر لتكنولوجيـا المعلومـات على الميزة التنافسـية بأبعادهـا المختلفـة وبالتالـي نقبـل الفرضيـة الرئيسـة الثانية و الفرضيـات الفعيـة المنبثقة عنهـا. و هذا يتفق مـع در اسـة ( Wang and ( others, 2006 ودر اسـة ( Daneshvar, 2010 ). 
الجهود الر اميـة إلى إثراءو تعزيز دور تكنولوجيا المعلومات في . المنظمــة و خلق بيئة تتظيمية محفزة لتحقيق الأداء المتميز.

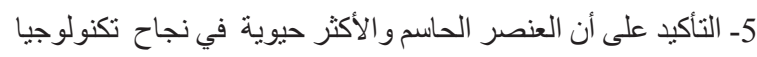

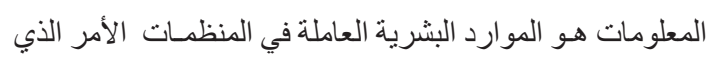
يتطلب اهتمـام الإدارة العليا و حرصها على جذب و تعيين ذوي الكفاءات والمــؤهلات العاليـة واستمرار تطــويرها و وتتميتها

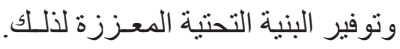

$$
\text { يظهر من جدول (16) ما يلي: }
$$

1- عدم وجـود فروق ذات دلالـة إحصائيـة عند مسنتوى الدلالـة (0.05=

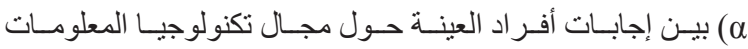

$$
\text { تعـزى للمتغيـر ات (المؤ هـل العلمـي، ومــدة الخدمــة، و العمـر ). }
$$

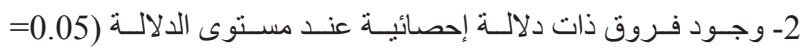

ه) بيـن إجابـات أفـر اد العينـة حـول مجــال تكنولوجيـا المعلومـات

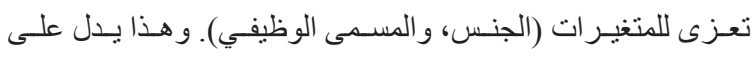

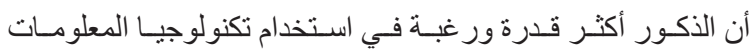
مـن الإنـاث و هذا يتفق مـع در اسـة ( الخو الـدة، 2008 ) وكذلك فـان الموظفيـن أكثـر اسـتخدام للتكنولوجيـا.

(النتائج

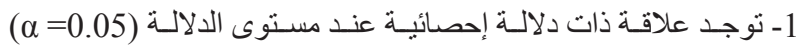
بيـن تكنولوجيـا المعلومـات و التكلفـة.

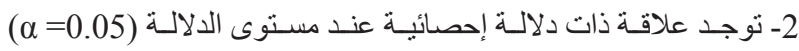
بيـن تكنولوجيـا المعلومـات و الجـودة.

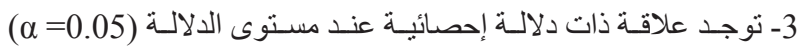
بيـن تكنولوجيـا المعلومـات و المرونـة.

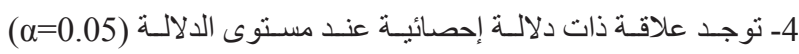
بيـن تكنولوجيـا المعلومـات و التسـليم.

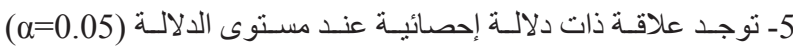
بيـن تكنولوجيـا المعلومـات و الإبـداع.

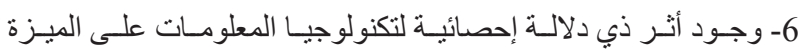
التنافسـية بأبعادهــا المختلفــة (التكلفـة، الجـودة، المرونــة، التسـليم،

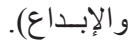

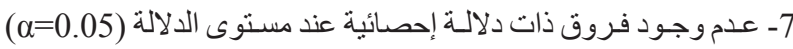

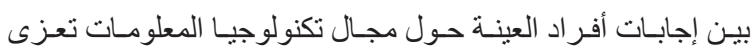

$$
\text { للمتغير ات (المؤ هـل العلمي، ومـدة الخدمـة، و العــر ). }
$$

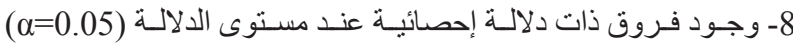

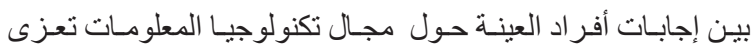
للمتغيـرات (الجنس، والمسـىى الوظيفي). 9ـ التوصيات

1- توجيه نظر المسئولين في المنظمـات إلى تكنولوجيـا المعلومـات و دور هما في تحقيق الميزة التنافسية.

2- تعميق و عي و إدر الك المسئولين في المنظمات للتحـديات الكبيـرة و المعوقـات المستمرة و المنافسة الثديدة التي تو اجهها المنظمـات حاضـر اً ومستقبلاً. 3- ضرورة أن يولي المســؤولون و المديـرون في المنظمـات اهتماماً زائداً لتكنولوجيــا المعلومــات و العمل على إنشاء قسم أو إدارة متخصصة لتكنولوجيــا المعلومات. 4- حث الإدارة العليا على بذل جهود مكثفة و متو اصلة لدعم و تعزيز 
and corporat social responsibility. Harvard Business Review, December: 78-92.

Wang, Qiang; Lai, Fujun; Zhao, Xiande (2006). Impact of Information technology on Competitive Advantage in Third-party Logistics Firms. Industrial Management \& Data Systems, vol. 106, number 9, pp1249-1271(23).

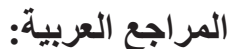

$$
\begin{aligned}
& \text { الجاســ، جعفـر (2005). تكنولوجيــا المعلومــات . عمــان : الأردن، دار } \\
& \text { أسـامة للنشـر و التوزيـع. } \\
& \text { الخو الــه، ريـاض، الحنيطي، محمـــ (2008) .أثر اسـتخدام تكنولوجيـا } \\
& \text { المعلومـات علـى الإبـــاع الإداري فـي المؤسســات العامــة }
\end{aligned}
$$

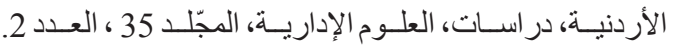

$$
\begin{aligned}
& \text { الزعبـي، حسـن علـي (2005). نظـم المعلومــات الإسـتر اتيجية، مدخـل } \\
& \text { اسـتر اتيجي. عمـان: دار و ائـل للنشــر و التوزيـع. } \\
& \text { الثـرفا، سـلوى (2008). دور إدارة المعرفة و تكنولوجيا المعلومات في } \\
& \text { تحقيق المز ايا التنافسية في المصارف العاملة في قطاع غزة، } \\
& \text { رسـالة ماجستير، الجامعـة الإســاميةــ غـزة. } \\
& \text { العامـري، صـالـح، الغالبـي، طاهـر (2008). الإدارة و الأعمــال، الطبعـة } \\
& \text { الثنانيـة، عمـان: دار وائـل للنشـر و التوزيـع. } \\
& \text { اللامسي، غسـان قاســ، البياتـي ، أميـرة شـكري(2010)، تكنولوجيـا } \\
& \text { المعلومـات في منظمـات الأعمـال. عمـان: مؤسســة الـور اق } \\
& \text { للنشـر و التوزيــع. } \\
& \text { جمعية وكلاء السياحة و السفر ؤرعز } \\
& \text { المراجع الأجنبية }
\end{aligned}
$$

Cakmak, Pinar Irlayici; TAS, Elcin (2012). The Use of Information Technology on Gaining Competitive Advantage in Turkish Contractor Firms. World Applied Sciences Journal 18(2):274-285.

J. W., Ong and Bin Ismail, Hishamuddin (2008) Sustainable Competitive Advantage through Information Technology Competence: ResourceBased View on Small and Medium Enterprises. In: 10th International-Business-InformationManagement-Association Conference, 30 JUN01 JUL 2008, Kuala Lumpur, MALAYSIA.

Kroenke, David, (2011), Using MIS, Prentice Hall.

Laudon, Kenneth \& Laudon, Jane, (2014), Management Information systems, 11th Ed, Prentice Hall Int. Inc.

Daneshvar, poolad (2010). Review of Information Technology Effect on Competitive AdvantageStrategic Perspective, International Journal of Engineering Science and Technology (IJEST), Vol.2(11), 6248 - 6256.

Porter, Michael E., Kramer, Mark R. (2006). Strategy and society; the link between competitive advantege 